\title{
FOSB wt Allele
}

National Cancer Institute

\section{Source}

National Cancer Institute. FOSB wt Allele. NCI Thesaurus. Code C52889.

Human FOSB wild-type allele is located in the vicinity of $19 q 13.32$ and is approximately 7 $\mathrm{kb}$ in length. This allele, which encodes fosB protein, plays a role in the suppression of transcription by RNA polymerase II. 